\title{
Modelling The Influence Of Workplace Spirituality, Quality Of Work Life, Expectations Towards Work On Commitment To Long- Term Career Of Employees In Gauteng Province, South Africa
}

Elizabeth Chinomona, Vaal University of Technology, South Africa

\begin{abstract}
Businesses are getting better, bigger, more integrated and more complex in this era. The recognition of the influence and importance of quality of work life can be beneficial to employees and employers in a business. If an employee's expectation are met, they have a clear and concise perception toward their work contributing to long-term career. The principle of this study is to demonstrate the influence of quality of work life, expectations towards work and perception of work on commitment to long-term career on the employees in the Gauteng province of South Africa. A quantitative research design was utilized and a sample of 250 employees in managerial and non-managerial employees was used. The study uses smart PLS to do data analysis. The outcomes of this study showed the acceptance of all the hypotheses that there is a significant influence of quality of work life, expectations towards work and perception of work life on commitment to long-term career.
\end{abstract}

Keywords: Workplace Spirituality; Quality of Work Life; Expectations Towards Work; Commitment to Long Term Career; Affective Events Theory

\section{INTRODUCTION}

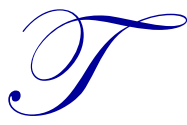

he aspects of long term career of employees within an organization remains an important factor regarding the success of any business in this twenty-first century. "Currently, some of the factors shaping the world of work and its situated nature include global shifts in the economy, mandatory retirement changes, the growing number of immigrant or older or migrant workers, the offshoring of work from one country to another and the discourses about future work possibilities" (Baruch, 2006:125). Urbanowski (2012:17) noted that in the manufacturing sector unemployment is high in the western world and there is the emergence and acceptance of service work. Therefore, quality of work life, workplace spirituality and expectations towards work needs to be taken seriously.

Coetzee, Bergh and Schreuder (2010:127) stipulates that organizations that offer employees personal growth and development opportunities by way of career-development support practices will possibly gain more benefits by ensuring that employees truly recognize how to proactively manage their own career. "Ironically, the fear of losing valuable employees repeatedly comes to the fore as one of the key reasons why career-development support processes are not made accessible to employees" (Baruch, 2006:128). However, a lack of organizational support generally has long-term negative effects on an organization's financial status, because a lack of organizational commitment is associated with poor job performance, low morale and lower job satisfaction (Ferreira, Basson \& Coetzee, 2010). 
Membership of employees who come into the organization with varying needs and believes that such needs matters a lot because they can only be attained the benefits through their membership of the organization. They see the organization as a path through which their needs can be satisfied. However, "their membership of the organization alone cannot help them achieve these needs except that they are shown the rope to growth to help them achieve their career goals. In recognition of this fact, an important trend in business in the twenty-first century is a focus on commitment to long term career" (Shellenbarger, 2000:30). To this end, spirituality in general, and in the workplace in particular, has become an important topic in recent years (Nwibere \& Emecheta, 2012).

Contributions of this study to commitment to long term career is that it develops a theoretical model that examines the relationships of workplace spirituality, expectations towards work and quality of work life as fundamental predictors to commitment to long term career within the different business environments. The rest of the paper is presented as follows: A problem statement is constructed, the theoretical model is developed after which demonstrates the relationships and hypotheses of the variables. This will be followed by the methodology, data analysis and conclusions of the study. Limitations and recommendations will be presented at the end of the paper.

\section{PROBLEM STATEMENT}

Provided the importance of long term commitment to career by employees, more information into its factors affecting long term career and its consequences are needed to help organizations improve their level of retaining employees. Srikanth and Israel (2012) states that individuals who are rated low on career commitment will be unproductive in the organization. Lapalme, Tremblay and Simard (2009) indicates that organizational restructuring places increased pressure on employees and causes devoted workers to question their commitment to the organization.

Few studies have focused on a more detailed model identifying the influence of antecedents such as workplace spirituality, expectations towards work and quality of work life on commitment to long term career. Researchers such as (Lapalme et al. 2009) focused on supervisor support, organizational support and psychological distress as antecedents to commitment to career. Other researchers such as Poon (2013), Ferreira, et al. (2010), Srikanth and Israel (2012) have studied these variables in different context.

In light of the aforementioned gap, the purpose of this study is to examine the impact and consequences of commitment to long term career by employees in different sections of business in South Africa. Inspecting the impact of workplace spirituality, expectations towards work and quality of work life on the commitment to long term career will be useful information to human resource practitioners in determining the success of their organizations. The input of this study to literature is that it develops new hypotheses and theoretical model showing the relationship workplace spirituality, expectations towards work and quality of work life on commitment to long term career by employees, which is essential for both employees and organizations.

\section{LITERATURE REVIEW}

This paper reviewed literature on the Affective Events Theory (AET), quality of work life, expectations towards work, perception of work life plus commitment to long term career.

\section{Affective Events Theory (AET)}

AET is model developed by "organizational psychologists to explain how emotions and events influence job performance and job commitment” (Thompson \& Phaua, 2012:276)._AET explains the linkages between employees' internal influences and their reactions to incidents that occur in their work environment that affect their performance, organizational commitment and job satisfaction. The theory recommends that affective work behaviors are explained by employee moods and emotions, while cognitive-based behaviors are the best predictors of job satisfaction which makes sense (Wegge, Van Dick, Fisher, West \& Dawson, 2006). "The theory proposes that positiveinducing as well as negative-inducing emotional incidents at work that are distinguishable and have a significant psychological impact upon workers' job satisfaction. This results in long lasting internal and external affective reactions exhibited through job performance, job satisfaction and organizational commitment" (Wegg et al., 2006:237). 
Crede, Chernyshenko, Stark, Dalal and Bashshur (2007) argued that some research suggests that job satisfaction mediates the relationship between various antecedent variables such as dispositions, workplace events, job characteristics, job opportunities and employee behavior exhibited while on the job. To that effect, when workers experience uplifts or hassles, their intention to continue or quit depends upon the emotions, moods and thoughts associated with the satisfaction they derive from their jobs (Weiss \& Beal, 2005). Relationship between job satisfaction and turnover is fully mediated by intention to quit. Workers who report low job satisfaction are likely to engage in planned quitting (Mobley, 1977).

Regarding affective events theory to the recent study, the study accepts that due to the imbalance of employee retention and retirements within an organization, workplace spirituality, expectations towards work and quality of work life forms part of affective events and emotions encountered by employees which ultimately leads to commitment to long term careers.

\section{Workplace Spirituality}

Duchon and Plowman, (2005) proposes that workplace spirituality or spirituality in the workplace is about the recognition that meaningful work and sense of community are essential for the spiritual growth of employees. Spirituality in the workplace is about individuals and organizations seeing work as a spiritual path, as an opportunity to grow and to contribute to society in a meaningful way. "The spirituality view is that work is not just meant to be interesting or challenging, but that it is about things such as searching for deeper meaning and purpose, living one's dream, expressing one's inner life needs by seeking meaningful work, and contributing to others" (Ashmos \& Duchon, 2000:135). "Economic activities reflect the will, experiences and emotions of people and thus reveal human nature and moral content. With the formation of a knowledge-based economy and the acceleration of material satisfactions due to technological advancements at the end of the 20th century, many people began to exhibit spiritual emptiness, moral abnormalities, twisted social values, greed and all kinds of crimes because of the imbalance between their material and spiritual lives" (Chen \& Sheng, 2013:267).

\section{Expectations Towards Work}

Shaw (2013) states that employees today can expect more periods of spasmodic work disturbance and disinterestedness as part of their employment trajectory due to the irregularity of and unhinged global economies. Shaw (2013) has identified five predominant themes to expectations towards work in the new generation which are work/life balance, good pay and benefits, opportunities for advancement, meaningful work experiences, nurturing work environment. Zhang, Straub and Kusyk, (2007) shows that generation Y pupils have reportedly seen their parents work long hours, only to fall victim to corporate downsizing, frequent layoffs and high divorce rates. As a result, they have become wary of being put in the same position, and choose "making a life" over "making a living" (Zhang et al. 2007).

\section{Quality of Work Life}

Torlak, Tiltay, Ozkara and Dogan (2014) describes quality of work as related to employees feeling good. Satisfaction of an individual's needs at their workplace comprises the quality of work life. An individual's necessity set involves respect, self-fulfillment, information, aesthetics, health and security requirements, economic and domestic needs. Ganguly (2010) pinpointed that quality of work life has become an umbrella term for severity of activities which differentiates individuals and working conditions. Quality of work life is seen as a basic tool which boosts working conditions from an employee's perspective and provides a great organizational productivity (Permarupan, Al-Mamun \& Saufi, 2013: 269). On the other hand, Lee, Dai, Park and Mccreary, (2013) argues that it refers to the employee's satisfaction with working life and it is seen as a subjective phenomenon which is influenced by employee's perceptions of working conditions.

\section{Commitment to Long Term Career}

Srikanth and Israel (2012:137) defines career commitment as" one's attitude towards one's profession or vocation. Career Commitment is characterized by strong sense of identification, persuasion, development and active 
involvement in individual career goals. In other words, it is commitment to one's career goals". Career commitment or occupational commitment has also been conceptualized in three approaches by Meyer, Allen and Smith, (2007). "The first approach deals with affective commitment to an individual's career based on strong desire to remain in the same profession. The second is concerned with normative commitment with a sense of obligation to remain in the chosen profession and the third with continuance commitment which is concerned with high costs associated with leaving the occupation" Meyer et al. 2007:538).

\section{CONCEPTUAL FRAMEWORK AND HYPOTHESIS DEVELOPMENT}

Depiction based from the discussed literature review from commitment to long term career, a conceptual model is developed in figure 1 . The model is composed of four variables which are workplace spirituality, expectations towards work, quality of work life and commitment to long term career. Workplace spirituality, expectations towards work and quality of work life all influence employees to commitment to long term career in an organization. Workplace spirituality, expectations towards work and quality of work life are the predictors and commitment to long term career is the outcome variable. A detailed discussion of the relationships among these constructs is presented and the hypotheses are developed thereafter.

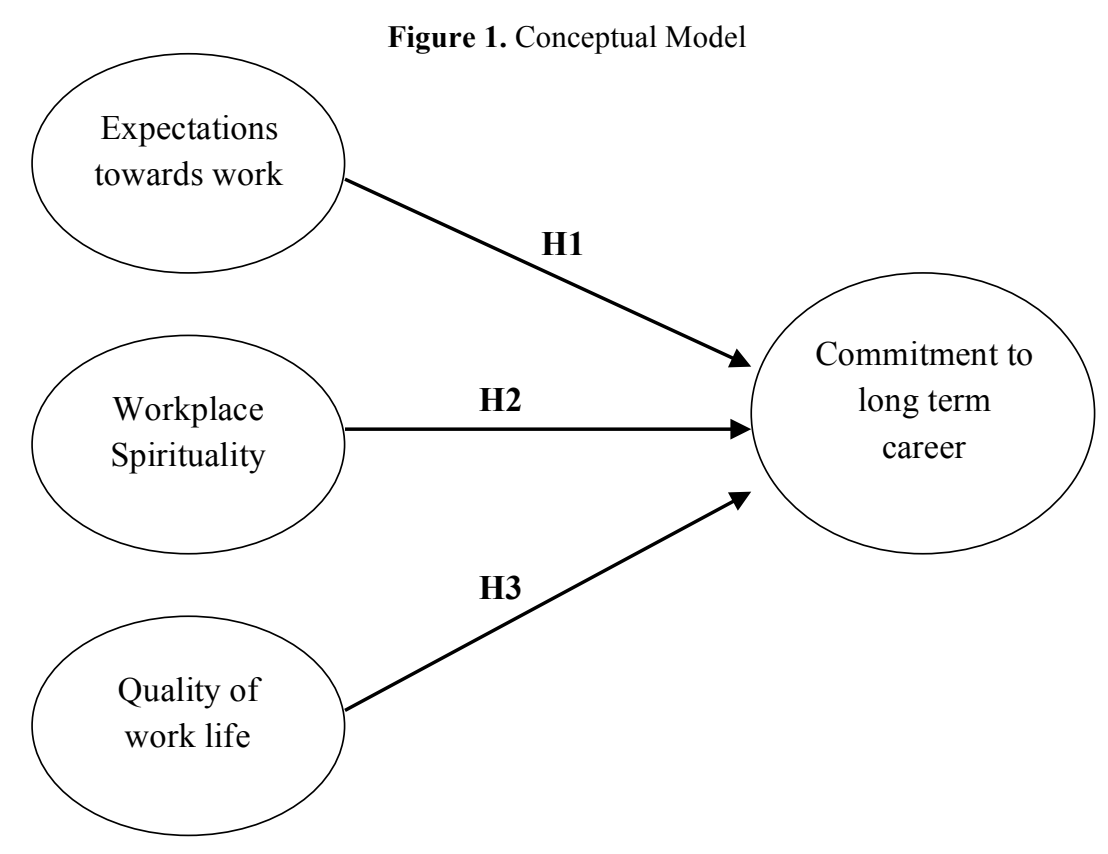

\section{Workplace Spirituality and Commitment to Long Term Career}

Attitudes of employees in organizations with high levels of workplace spirituality are positive, supportive of the organization, and demonstrate commitment to a much greater degree than in organizations without such values (Badrinarayanan and Madhavaram, 2008). Dimension of workplace spirituality represents how employees` interact with their day-to-day work at the individual level. A study by Riasudeen and Prabavathy (2011:29) present findings that spirituality in workplace will lead to increased ingenuity, honesty, trust, personal fulfilment and commitment to the job and organization, which ultimately lead to improved organizational performance. Therefore, this study supports the notion that workplace spirituality leads to commitment to long term career. Based on this premise, the following hypothesis is developed:

H1: There is a positive relationship between workplace spirituality and commitment to long term career. 


\section{Expectations Towards Work and Commitment to Long Term Career}

Employee commitment results from the actual state regarding the working conditions as perceived by an employee, whereas a positive perception fosters the felt commitment. "However, it has to be seen that the assessment of the actual state may be put into perspective by individual expectations that define the aspiration level of an individual" (Stefan \& Kleiner, 2007:252). Barnett (2012) argued that commitment may hence be influenced by surpassing the aspiration level. Barnett (2012) noted that employees often are surprised and disappointed by the difference between their expectations about and the realities of work. Therefore, the fulfillment of desired expectations by organizations will results in long term commitment by employees such that:

H2: There is a positive relationship between expectations towards work and commitment to long term career.

\section{Quality of Work Life and Commitment to Long Term Career}

Torlak et al. (2014) acknowledged that great quality of work life results in an increase in employee's job satisfaction and their performances, and at the same time, causes a decrease in both alienation and labor turnover. Koonmee, Singhapakdi, Virakul and Lee (2010) argued that quality of work life have a positive impact on job-related outputs such as employees' job satisfaction, employee commitment to organization and building team spirit. A study by Zare, Haghgooyan and Asl (2014: 41) quoted that "quality of work life initiatives are equally beneficial for the employers as it positively nurtures a more flexible, loyal, and motivated workforce, which is essential in determining the company's competitiveness and thus leads to commitment to career". In light of this notion, it is proposed that:

H3: There is a positive relationship between quality of life and commitment to long term career.

\section{MEASUREMENT INSTRUMENTS}

"Research scales were designed on the basis of previous work. Proper modifications were made in order to fit the current research context and purpose" (Chinomona \& Dhurup, 2016:8). Expectations towards work was measured using four-item scales adapted from Shaw (2013). Perception of work life' used a three-item scale measure; all were adapted from Luthans (2005). Quality of work life used a three-item scale measure; all were adapted from Rathamani and Ramchandra (2013). Commitment to long term career was measured using a three-item scale taken from SanchezVidal, Cegarra-Leiva and Cegarra-Navarro (2012). All were measured on a five-point Likert-type scale that was anchored by 1 (strongly disagree) to 5 (strongly agree) in order to express the degree of agreement (Chinomona \& Dhurup, 2016).

\section{Sample Description}

The study distributed questionnaires to different respective employees in the Gauteng province in South Africa. Out of 310 questionnaires which were distributed, 285 were returned and out of these 285 questionnaires, only 250 were usable. This yielded a valid response rate of about $81 \%$. Descriptive statistics in Table 1 show the gender, marital status, and age of employees. As indicated in Table 1 below, this study shows that males occupy greater percentage in the Gauteng companies and constitute $72 \%$ of the total target population. Females also employed in the companies but not more often as males though they constitute only $28 \%$ of the total population. The most active age group is that between 31 and 60 years which constitute $42 \%$ of the total population, followed by those between 31 and 60 years and last those above 60 years, constituting $36 \%$ and $22 \%$ respectively. Respondents who are married constitute $70 \%$ of the total population and the remainder is single which constitute $30 \%$ of the total population. 
Table 1. Sample demographic characteristics

\begin{tabular}{l|c|c}
\hline Gender & Frequency & Percentage \\
\hline Male & 180 & $72 \%$ \\
\hline Female & 70 & $28 \%$ \\
\hline Total & $\mathbf{2 5 0}$ & $\mathbf{1 0 0} \%$ \\
\hline Age & & $36 \%$ \\
\hline$\leqq 30$ & 90 & $42 \%$ \\
\hline $31-60$ & 105 & $22 \%$ \\
\hline$\geqq 60$ & 55 & $\mathbf{1 0 0} \%$ \\
\hline Total & $\mathbf{2 5 0}$ & $70 \%$ \\
\hline Marital status & & $30 \%$ \\
\hline Married & 175 & $\mathbf{1 0 0} \%$ \\
\hline Single & 75 & $\mathbf{2 5 0}$ \\
\hline Total & & \\
\hline
\end{tabular}

\section{PATH MODELING RESULTS}

Reliability and validity of the measurement instruments proves to be so the study proceeded to test the proposed hypotheses. In total there are three hypotheses that are tested. In the path model, Expectation towards Work (EW), Perception of Work Life (QL) and Quality of Work Life (QW) are the predictor variables. Commitment to Long-Term Career (CC) are the sole outcome/dependent variable. Figure 2, below offers the proposed hypotheses and the respective path coefficients. The same results of the path coefficients are tabulated in Table 2 depicting the Item to Total correlations, Average variance extracted (AVE), Composite Reliability (CR) and Factor Loadings.

\section{Path Model Results and Factor Loadings}

Below is Figure 2, showing the path modelling results and as well as the item loadings for the research constructs. On the measurement instruments for Expectations towards work 1 of them was deleted which is EW3 due to the fact that the factor loadings were below 0.5 which is the recommended threshold. Also on Perception of work life, QL3 was deleted and on Commitment to long term career, CC3 was deleted because the factor loadings were below the cut-off point which is 0.5 . 
Figure 2. Path Modeling and Factor Loading Results

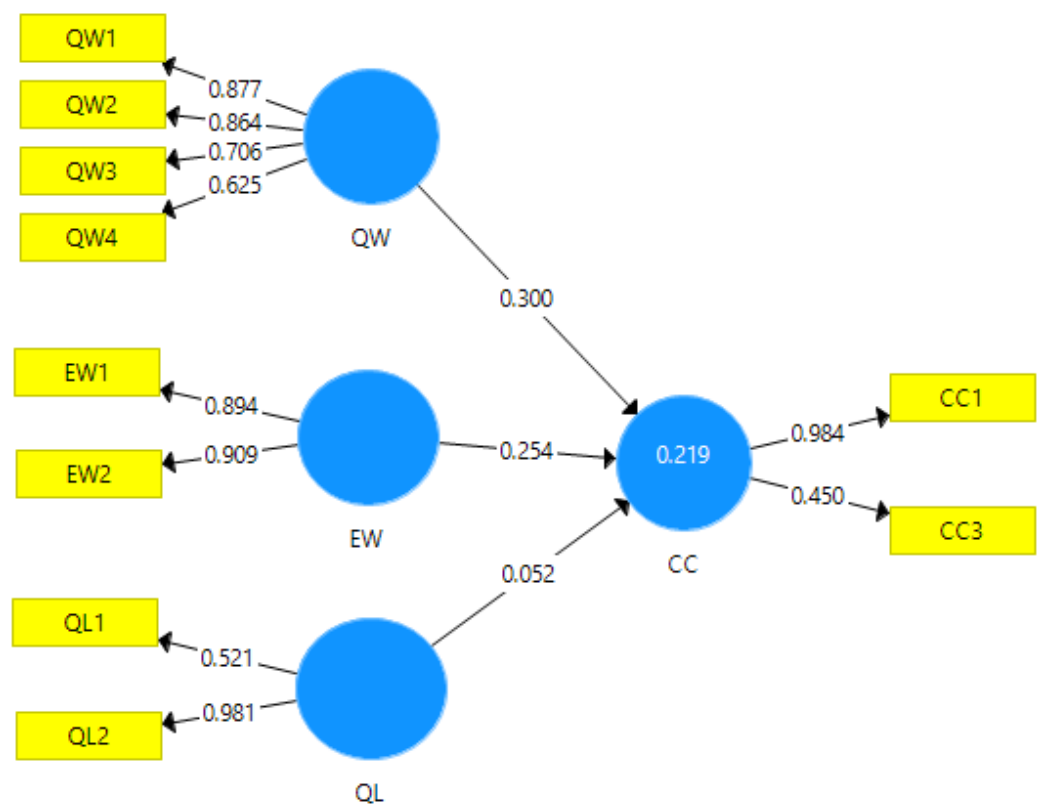

EW=Expectation towards Work; $Q L=$ Perception of Work Life; $Q W=$ Quality of Work Life; $C C=$ Commitment to Long-Term Career

Table 2, below present the research constructs, Cronbach alpha test, Composite reliability (CR), Average variance extracted (AVE) and item loadings. The lowest item to total loading is CC 2 with 0.449 and the highest is CC 1 with 0.911. On Factor loadings the lowest is 0.450 and the highest is 0.984 . It is important to note that 0.449 and 0.450 are below the threshold which is 0.500 but is we round off to the nearest whole number they will all become fairly acceptable which is exactly 0.500 .

This shows that the measurement instruments are valid. The lowest Cronbach alpha is 0.602 and the highest is 0.789 which shows that the constructs are very reliable and are explaining more that $60 \%$ of the variance.

Table 2. Measurement Accuracy Assessment and Descriptive Statistics

\begin{tabular}{|c|c|c|c|c|c|c|c|}
\hline \multirow[t]{2}{*}{ Research Variables } & \multicolumn{2}{|c|}{$\begin{array}{c}\text { Descriptive } \\
\text { statistics* }\end{array}$} & \multicolumn{2}{|c|}{ Cronbach's test } & \multirow[t]{2}{*}{ C.R. } & \multirow[t]{2}{*}{ AVE } & \multirow{2}{*}{$\begin{array}{c}\text { Item } \\
\text { Loadings }\end{array}$} \\
\hline & Mean & SD & Item-total & $\alpha$ Value & & & \\
\hline \multicolumn{8}{|l|}{ Quality of work life (QW) } \\
\hline QW 1 & 3.09 & 1.300 & 0.813 & 0.789 & 0.788 & 0.697 & 0.877 \\
\hline QW 2 & & & 0.839 & & & & 0.864 \\
\hline QW 3 & & & 0.689 & & & & 0.706 \\
\hline QW 4 & & & 0.606 & & & & 0.625 \\
\hline \multicolumn{8}{|l|}{ Expectations towards work (EW) } \\
\hline EW 1 & 2.10 & 1.173 & 0.856 & 0.700 & 0.700 & 0.652 & 0.894 \\
\hline EW 2 & & & 0.899 & & & & 0.909 \\
\hline \multicolumn{8}{|l|}{ Perception of work life (QL) } \\
\hline QL 1 & 2.01 & 1.070 & 0.501 & 0.602 & 0.602 & 0.504 & 0.521 \\
\hline QL 2 & & & 0.802 & & & & 0.891 \\
\hline \multicolumn{8}{|c|}{ Commitment to long-term career (CC) } \\
\hline $\mathrm{CC} 1$ & 3.05 & 1.002 & 0.911 & 0.653 & 0.654 & 0.500 & 0.984 \\
\hline $\mathrm{CC} 2$ & & & 0.449 & & & & 0.450 \\
\hline
\end{tabular}

EW=Expectation towards Work; $Q L=$ Perception of Work Life; $Q W=Q$ uality of Work Life; $C C=$ Commitment to Long-Term Career 
Table 3. Inter-Construct Correlation Matrix

\begin{tabular}{|c|c|c|c|c|}
\hline Variables & QW & $\mathbf{E W}$ & QL & $\mathrm{CC}$ \\
\hline QW & 0.590 & & & \\
\hline EW & 0.599 & 0.599 & & \\
\hline QL & 0.520 & 0.562 & 0.579 & \\
\hline $\mathrm{CC}$ & 0.460 & 0.533 & 0.458 & 0.575 \\
\hline
\end{tabular}

\section{Inter-Construct Correlation Matrix}

Nunnally and Bernstein, (1994) proves that one of the methods used to check on the discriminant validity of the research constructs was the evaluation of whether the correlations among latent constructs were less than 0.60 . " $\mathrm{A}$ correlation value of less than 0.60 is recommended in the empirical literature to confirm the existence of discriminant validity" (Nunnally \& Bernstein 1994:38). As can be seen all the correlations are below the standard level of 0.60 which indicate the existence of discriminant validity. The diagonal values in bold stands for the Shared Variances (SV) for the respective research constructs. The Shared Variance is expected to be greater than the correlation coefficients of the corresponding research constructs. Table 2, above shows that the results further validate the existence of discriminant validity.

Table 4. Results of Structural Equation Model Analysis

\begin{tabular}{|c|c|c|c|c|}
\hline Hypotheses Statements & Hypothesis & $\begin{array}{c}\text { Path coefficients } \\
(\beta)\end{array}$ & T-Statistics & $\begin{array}{l}\text { Decision on } \\
\text { Hypotheses }\end{array}$ \\
\hline $\begin{array}{l}\text { Quality of work life }(\mathrm{QW}) \rightarrow \\
\text { Commitment to long-term career }(\mathrm{CC})\end{array}$ & H1 & $0.300^{\mathrm{a}}$ & 6.979 & $\begin{array}{c}\text { Accept/ } \\
\text { Significant }\end{array}$ \\
\hline $\begin{array}{l}\text { Expectations towards work }(\mathrm{EW}) \rightarrow \\
\text { Commitment to long-term career }(\mathrm{CC})\end{array}$ & $\mathbf{H 2}$ & $0.254^{\mathrm{a}}$ & 5.610 & $\begin{array}{c}\text { Accept/ } \\
\text { Significant }\end{array}$ \\
\hline $\begin{array}{l}\text { Perception of work life (QL) } \rightarrow \\
\text { Commitment to long-term career (CC) }\end{array}$ & H3 & $0.052^{\mathrm{a}}$ & 3.143 & $\begin{array}{c}\text { Accept/ } \\
\text { Significant }\end{array}$ \\
\hline
\end{tabular}

${ }^{\mathrm{a}}$ Significance Level $\mathrm{p}<.10 ;{ }^{\mathrm{b}}$ Significance Level $\mathrm{p}<.05 ;{ }^{\mathrm{c}}$ Significance Level $\mathrm{p}<.01$.

Table 4, above present the four hypothesized relationships, path coefficients, the t-statistics and the decision criteria. The value of the t-statistic will indicate whether the relationship is significant or not. T-statistics which is above 2 is accepted and shows a significant relationship. Drawing from the results provided in Table 4, four of the hypothesized relationships (H1, H2 \& H3) are significant.

\section{RESEARCH FINDINGS AND DISCUSSIONS}

Hypothesis One (H1): Quality of work life (QW) $\rightarrow$ Commitment to long-term career (CC)

It can be observed in Figure 1 and Table 4 that H1 (Quality of work life (QW) $\rightarrow$ Commitment to long-term career (CC)) is supported by the hypothesis result $(0.300)$ and is significant at t-statistics 6.979 . The strength of the relationship is indicated by a path coefficient of 0.300 . This implies that Quality of work life directly influence commitment to long-term career in a positive significant way. The better the level of quality of work life the higher the level of commitment to long-term career.

Hypothesis Two (H2): Expectations towards work (EW) $\rightarrow$ Commitment to long-term career (CC)

Figure 1 and Table 4 above, indicate that H2 (Expectations towards work (EW) $\rightarrow$ Commitment to long-term career (CC)) is supported by the hypothesis finding (0.254) and is significant at t-statistics 5.610. Again, the strength of the association is indicated by a path coefficient of 0.254 . This implies that expectations towards work (EW) is positively related to commitment to long-term career (CC) in a significant way. Thus higher levels of expectations towards work will lead to higher levels of commitment to long-term career 
Hypothesis Three (H3): Perception of work life (QL) $\rightarrow$ Commitment to long-term career (CC)

It is depicted in Figure 1 and Table 4 that $\mathrm{H} 3$ (Perception of work life (QL) $\rightarrow$ Commitment to long-term career (CC)) is supported significantly. The t-statistics is 3.143 . The strength of the relationship is indicated by the path coefficient of 0.052. This finding suggests that perception of work life has a direct positive effect on commitment to long-term career. So the more effective the perception of work life, the more the commitment to long-term career.

\section{IMPLICATIONS OF THE STUDY}

Overall, an investigation of the research findings, indicate that Quality of work life (QW) $\rightarrow$ Commitment to longterm career (CC) has the strongest influence on each other (0.300) when compared to other research constructs. Expectations towards work (0.254) and perception of work life (0.052) follows having impact on commitment to longterm career. These findings have practical implications to investment managers in the financial sector. Drawing from the results, the findings indicate that managers for companies in the Gauteng province ought to put more focus on strategies that enhance quality of work life because it is likely to yield the desired higher commitment to long-term career when compared to other research constructs.

\section{LIMITATIONS AND FUTURE RESEARCH SUGGESTIONS}

Limitations were observed during this research. First, the study was restricted to four factors only; namely expectation towards work, perception of work life, quality of work life and commitment to long-term career. Future research could also include factors such as workplace spirituality, ethical climate and organizational citizenship behaviors. In addition, the results are based on a sample of 250 respondents which is not a bigger sample. This makes it difficult to generalize the results to other contexts in South Africa. Other researchers could make use of large sample sizes in order to get more representative views. This study focused on a purely quantitative research approach, other researchers could also try to use a mixed method approach or qualitative research so that in depth views of employees in the Gauteng province of South Africa can also be taken into consideration.

\section{CONCLUSIONS AND MANAGERIAL INFERENCES}

The study authenticates that factors such as expectation towards work, perception of work life and quality of work life are instrumental stimulating the commitment to long-term career in South Africa. In addition, quality of work life has a stronger impact on commitment to long-term career when compared to expectations towards work and perception of work life.

Theoretical and managerial implications are both observed in this study. Theoretically, this study makes a noteworthy progression in human resource theory by methodically examining the interplay between expectation towards work, perception of work life, quality of work life and commitment to long-term career. In this manner, the study is an important contributor to the existing literature on this subject.

On the practical front, as expectation towards work, perception of work life and quality of work life were exerted as having positive influence on commitment to long-term career, improvements in each of these three factors could stimulate higher commitment to long-term career in companies in the Gauteng province of South Africa. Quality of work life can be improved by, among other things giving employees empowerment and responsibility in the duties of the work that they do. In addition, perception of work life could be improved by implementing equity rules, regulations and remuneration. To increase expectation towards work managers should implement policies that are favourable to everyone not just to few individuals. To increase commitment to long term career workers should be treated as individuals not machines without blood. They should be given things like vacation holidays and special leave days.

\section{AUTHOR BIOGRAPHY}

Dr. Elizabeth Chinomona is a married woman with three children. Her first degree is from the University of Zimbabwe and her Masters is from National Cheng Kung University in Taiwan. Currently, Dr. Chinomona is working as a lecturer at Vaal University of Technology in the Logistics Department, South Africa. She graduated with her Ph.D 
this year from the same university. Research her passion as she has always learned a lot from it and also disseminate knowledge to others. Her research areas include entrepreneurship, marketing, supply chain, organizational behaviour and human resources management. She has published more than 30 articles in accredited Journals and more than 10 in non-accredited Journals.

\section{REFERENCES}

Ashmos, D.P., \& Duchon, D. (2000). Spirituality at work: Conceptualization and measure, Journal of Management Enquiry, 9(2), 134-161.

Badrinarayanan, V., \& Madhavaram, S. (2008). Workplace Spirituality and the Selling Organization: A Conceptual Framework and Research Propositions, Journal of Personal Selling \& Sales Management, 18(4), 421-434.

Barnett, K. (2012). Student Interns' Socially Constructed Work Realities: Narrowing the Work Expectation-Reality Gap, Business Communication Quarterly, 75(3), 271-290.

Baruch, Y. (2006). Career development in organizations and beyond: Balancing traditional and contemporary viewpoints. Human Resource Management Review, 16, 125-138.

Chen, M., \& Sheng, C. (2013). Workplace Spirituality and Earnings Management Motivations, International Journal of Business and Information, 8(2), 267-298.

Chinomona, E \& Dhurup, M. (2016). The effects of organisational commitment and employee perceptions of equity on organisational citizenship behaviour in Zimbabwean SMEs. South African Journal of Labour Relations, 40(2), 1-22.

Coetzee, M., Bergh, Z.C., \& Schreuder, A.M.G. (2010). Subjective work experiences: Exploring the influence of career orientations, psychological career resources and factors of job/career satisfaction/ dissatisfaction. Unpublished research report, Department of Industrial and Organisational Psychology, University of South Africa, Pretoria, 123-167.

Crede, M., Chernyshenko, O.S., Stark, S., Dalal, R.S., \& Bashshur, M. (2007). "Job Satisfaction as Mediator: An assessment of Job Satisfaction's Position Within the Nomological Network.", Journal of Occupational and Organizational Psychology, 80(3), 515-538.

Duchon, D. P. \&. Plowman, D. A. (2005). Nurturing Spirit at Work: Impact on Work Unit Performance, The Leadership Quarterly, 16, 807-833.

Ferreira, N., Basson, J., \& Coetzee, M. (2010). Psychological career resources in relation to organizational commitment: An exploratory study. SA Journal of Human Resource Management, 1(1), 1-10.

Ganguly, R. (2010). Quality of Work Life and Job Satisfaction of a Group of University Employees, Asian Journal of Management Research, 209-216.

Koonmee, K., Singhapakdi, A., Virakul, B., \& Lee, D. J. (2010). Ethics institutionalization, Quality of work life, and employee job-related outcomes: A survey of human resource Managers in Thailand. Journal of Business Research, 63(1), 20-26.

Lapalmea, M, Tremblayb, M., \& Simarda, G. (2009). The Relationship Between Career Plateauing, Employee Commitment and Psychological Distress: The Role of Organizational and Supervisor Support, The International Journal of Human Resource Management, 20(5), 1132-1145.

Lee, Y., Dai, Y., Park, C., \& Mccreary, L.L. (2013). Predicting Quality of Work Life on Nurses Intention to Leave, Journal of Nursing Scholarship, 45(2), 160-168.

Linda, W. N., Schweitzer, S. T., \& Lyons, J. (2010). New Generation, Great Expectations: A Field Study of the Millennial Generation, Business Psychology, 25, 281-292.

Luthans, F. (2005). Organizational behavior. Tenth edition. New York: McGraw-Hill. MOSS, S. Fit indices for structural equation modeling. Available at: <www.psych-it.com.au/Psychlopedia/article.asp?id=277>. Accessed: 09/01/2014.

Meyer, H. R, Allen, N. J., \& Smith, C. A. (2007). Commitment to Organizations and Occupations: Extension and Test of a Three- Component Conceptualization", Journal of Applied Psychology, 78, 538-573.

Mobley, W. H. (1977). "Intermediate Linkages in the Relationship Between Job Satisfaction and Employee Turnover." Journal of Applied Psychology, 62(2), 237-240.

Nwibere, B. M., \& Emecheta, B. C. (2012). Workplace Spirituality and Employees' Commitment to the Organization: A Study of Selected Banks in the South-South Geo-Political Region of Nigeria, International Journal of Business and Public Administration, 9(3), 123-147.

Nunnally, J., \& Bernstein, I. (1994). Psychometric theory. (3rd Edition). New York: McGraw-Hill.

Permarupan, P.Y., Al- Mamun, A., \& Saufi, R.A. (2013). Quality of Work Life on Employees Job Involvement and Affective Commitment between the Public and Private Sector in Malaysia. Asian Social Science, 9(7), 268-278.

Poon, M.L. (2013). Relationships Among Perceived Career Support, Affective Commitment, and Work Engagement, International Journal of Psychology, 48(6), 1148-1155.

Rathamani, P., \& Ramchandra, R. (2013). A study of work life of employees in textile industry - Sipcot, Perundurai. Journal of Business and Management, 8, (3), 54-59.

Riasudeen, S., \& Prabavathy, R. (2011). Relationship of Workplace Spirituality and Work Attitude in Manufacturing Organisation. Global Management Review, 5(4), 29-37. 
Sanchez-Vidal, M. E., Cegarra-Leiva, D., \& Cegarra-Navarro, J. G. (2012). Gaps between managers' and employees’ perceptions of work-life balance. The International Journal of Human Resource Management, 23(4), 645-661.

Shaw, L. (2013). Are we ready to address the new expectations of work and workers in the transforming world of work? Work 44, IOS Press: $3-9$.

Shellenbarger, S. (2000). More relaxed boomers, fewer workplace frills and other job trends. Wall Street Journal, December, 27, 1-37.

Srikanth, P.B., \& Israel, D. (2012). Career Commitment \& Career Success: Mediating Role of Career Satisfaction. The Indian Journal of Industrial Relations, 48(1), 137-149.

Stefan, S., \& Kleiner, M. (2007). The Psychological Relationship between Companies and Freelancers: An Empirical Study of the Commitment and the Work-related Expectations of Freelancers. The Psychological Relationship Between Companies and Freelancers. Management Review, 18(3), 252-270.

Thompson, E. R., \& Phua, F.T.T. (2012). A Brief Index of Affective Job Satisfaction", Group \& Organization Management, 37, (3), 275-307.

Torlak, O., Tiltay, M., Ozkara, B.Y., \& Dogan, V. (2014). The Perception of Institutionalisation of Ethics and Quality of WorkLife: The Perspective of Turkish Managers, An Interdisciplinary Journal of Social Business, 170-180.

Urbanowski, R. (2012). Three scenarios where an Occupational Science Perspective was used to inform Public Policy. Canadian Society of Occupational Scientists Conference on Fostering Inter professional Excellence in Occupation. University of Alberta. Edmonton, Canada, 1-34.

Wegge, J., Van Dick, R., Fisher, G.K., West, M.A., \& Dawson, J.F. (2006). A Test of Basic Assumptions of Affective Events Theory (AET) in Call Centre Work". British Journal of Management, 17(3), 237-254.

Weiss, H.H \& Beal, D. J. (2005). The Effect of Affect in Organizational Settings. Emerald Group Publishing Limited. USA.

Zare, H., Haghgooyan, Z., \& Asl, Z.K. (2014). Identification The Components of Quality of Work Life and Measuring Them in Faculty Members of Tehran University, Iranian Journal of Management Studies (IJMS), 7(1), 41-66.

Zhang, Y., Straub, C., \& Kusyk, S. (2007). Making a Life or Making a Living? Cross-Cultural Comparisons of Business Students Work and Life Values in Canada and France. Cross Cultural Management, An International Journal, 14, 174-195. 


\section{NOTES}

